\title{
Efisiensi Pemberian Air dan Kompos Terhadap Mineralisasi NPK Pada Tanah Regosol
}

\author{
Efficiency of Water Supply and Compost on NPK Mineralization in Regosol
}

Venus Nikiyuluw ${ }^{1}$, Rudy Soplanit ${ }^{2}$, Adelina Siregar ${ }^{2, *}$

\author{
${ }^{1}$ Program studi Agroteknologi, Jurusan Budidaya Pertanian, Fakultas Pertanian, Universitas Pattimura \\ ${ }^{2}$ Jurusan Budidaya Pertanian, Fakultas Pertanian, Universitas Pattimura \\ Jl. I. M. Puttuhena, Kampus Poka Ambon, 97233 \\ *Penulis Korespondensi: E-mail: siregar.adelina@gmail.com
}

\begin{abstract}
Good soil contains sufficient nutrient content for plants. Some of the most important nutrients in the soil include nitrogen, phosphorus, and potassium. However, regosol soil cannot provide enough nutrients and water. The objectives of this study include: 1) comparing the volume of water given with a frequency of 1, 2 or 3 days for NPK nutrient availability on regosol soils; 2) determining the amount of NPK nutrients available after 30 days of incubation by giving different compost doses; 3) determining the interaction between the frequency of water supply and decomposition of organic matter in providing NPK nutrients to regosol soils. This study used a completely randomized design method with a $3 \times 3$ factorial pattern with 3 replications, therefore there were 27 experimental units. Data analysis of the observed variables was done using variance analysis with SAS program ver 9.0 and if there was a real treatment effect followed by a different test between treatments using BNT (5\%). Compost applied to the soil was done, this was indicated by a low C / N value of 14.3 and in accordance with the SNI value standards of 10-20. The results of the study showed that the application of water and organic matter independently has a significant effect on the $N$ content, $P$, and $K$ in the ground. Whereas, the interaction between the two treatments of water frequency application and organic matter had no significant effect on the levels of $N, P$, and $K$ in the soil. The conclusion of this study, with the application of water once every 3 days and the treatment of 300g/pot organic matter (B2) was best to provide the highest Ntotal value (0.53\%), P available (17, $50 \mathrm{mg} / \mathrm{kg}$ ), and Kexch (2.03 me/100 $\mathrm{g}$ ).
\end{abstract}

Keywords: compost, frequency of water supply, regosol

\section{ABSTRAK}

Tanah yang baik memiliki kandungan hara yang cukup bagi tanaman. Beberapa unsur hara yang terpenting dalam tanah antara lain ialah nitrogen, fosfor dan kalium. Tetapi tanah regosol tidak dapat menyediakan unsur hara dan air dengan cukup. Tujuan dari penelitian ini antara lain: 1) membandingkan volume air yang diberikan dengan frekwensi 1, 2 atau 3 hari sekali untuk ketersediaan hara NPK pada tanah regosol; 2) menetapkan banyaknya unsur hara NPK tersedia setelah 30 hari inkubasi dengan pemberian dosis kompos yang berbeda; dan 3) mengetahui interaksi antara frekwensi pemberian air dan dekomposisi bahan organik dalam menyediakan hara NPK pada tanah regosol. Penelitian ini menggunakan metode Rancangan Acak Lengkap dengan pola faktorial $3 \times 3$ dengan 3 ulangan sehingga terdapat 27 satuan percobaan. Analisis data dari variabel yang diamati menggunakan analisis ragam dengan program SAS ver 9.0 dan jika terdapat pengaruh perlakuan yang nyata dilanjutkan dengan uji beda antar perlakuan menggunakan BNT (5\%). Kompos yang diaplikasi ke tanah sudah matang, hal ini ditandai dengan nilai $\mathrm{C} / \mathrm{N}$ yang rendah yaitu 14,3 dan sesuai dengan standar nilai SNI yaitu 10-20. Hasil penelitian menunjukkan bahwa pemberian air dan bahan organik secara mandiri memberikan pengaruh nyata terhadap kadar N, P, dan K dalam tanah. Sedangkan, interaksi antara kedua perlakuan air dan bahan organik tidak berpengaruh nyata terhadap kadar $\mathrm{N}$, P, dan $\mathrm{K}$ dalam tanah. Kesimpulan dari penelitian ini, dengan pemberian air 3 hari sekali dan perlakuan bahan organik 300g/pot (B2) adalah dosis yang lebih baik untuk mendapat nilai Ntotal, Ptersedia dan Kdd tertinggi yaitu $\mathrm{N}$ total $(0,53 \%), \mathrm{P}$ tersedia $(17,50 \mathrm{mg} / \mathrm{kg})$, dan K-dd (2,03 me/100 g).

Kata kunci: frekwensi pemberian air, kompos, regosol

\section{PENDAHULUAN}

Tanah merupakan media tumbuh tanaman. Tanah yang ideal dapat menunjang pertanian sehingga akan meningkatkan taraf hidup manusia. Tanah memiliki komposisinya terdiri dari: $25 \%$ udara, $25 \%$ air, $45 \%$ mineral dan $5 \%$ bahan organik. Atas dasar perbandingan ini, terlihat kebutuhan tanah terhadap bahan organik 
adalah yang paling kecil. Namun demikian kehadiran bahan organik dalam tanah mutlak dibutuhkan karena bahan organik merupakan bahan penting dalam menciptakan kesuburan tanah, baik secara fisik, kimia maupun dari segi biologi tanah (Hardjowigeno, 2003).

Tanah yang baik merupakan tanah yang memiliki kandungan hara yang cukup bagi tanaman. Beberapa unsur hara yang terpenting dalam tanah antara lain ialah nitrogen, fosfor dan kalium. Nitrogen membantu memperbaiki pertumbuhan vegetatif tanaman dan pembentukan protein. Seperti nitrogen, fosfor merupakan penyusun fosfolipid, nukleoprotein, dan fitin yang banyak tersimpan di dalam biji; berperan aktif dalam mentransfer energi di dalam sel, dan berfungsi untuk mengubah karbohidrat, serta dapat meningkatkan efisiensi kerja kloroplas. Kalium berperan dalam proses metabolis dan mempunyai pengaruh khusus dalam absorpsi hara, pembukaan stomata, transpirasi, kerja enzim dan berfungsi sebagai translokasi karbohidrat (Handayanto, 2007).

Tanah memerlukan air dalam menyiapkan hara larut bagi pertumbuhan tanaman. Air sangat berperan dalam mobilisasi unsur hara yang ada didalam tanah, karena unsur hara dapat diserap oleh tanaman, harus dalam bentuk tersedia (kation dan anion) dalam larutan tanah. Air diserap tanaman melalui akar bersama - sama dengan unsur - unsur hara yang terlarut di dalamnya. Pemberian air pada tanah haruslah sesuai dengan kebutuhan tanah dan tanaman tersebut. Hasil penelitian Marsha (2014) melaporkan pemberian air 75\% kapasitas lapang dengan frekuensi pemberian air tiga hari sekali mampu meningkatkan produktivitas tanaman Crotalaria mucronata Desv pada tanah Latosol. Selain itu, Nugraha (2013) melaporkan kekurangan air dapat menyebabkan penurunan pertumbuhan dan hasil pada tanaman kedelai. Oleh sebab itu manajemen air yang baik sangat membantu dalam proses pengelolaan dan pemanfaatan air yang maksimal.

Salah satu bentuk manajemen air ialah menghitung kebutuhan air tanaman yang dapat dilakukan dengan menggunakan metode pengukuran Cropwat for Windows version 9.0. Cropwat merupakan sebuah program komputer untuk perhitungan kebutuhan air tanaman dan kebutuhan irigasi berdasarkan data tanah, iklim dan tanaman yang dikembangkan oleh Divisi Pengembangan Tanah dan Air FAO pada tahun 1999. Hasil penelitian Pristianto dan Mulyadi (2015) melaporkan bahwa penggunan model Cropwat dapat membantu memperkirakan kebutuhan air tanaman jagung untuk menekan penurunan hasil tanaman jagung yang disebabkan oleh pengaruh cekaman air dan kondisi iklim pada lahan irigasi dan tadah hujan. Selain itu Cropwat dapat digunakan untuk penjadwalan irigasi dengan baik dan dapat mengurangi jumlah pemberian air irigasi tanpa terjadi penurunan hasil produksi (Schahbazian et al., 2007).

Tanaman memerlukan air dan unsur hara dari tanah. Tetapi tanah regosol tidak dapat menyediakan unsur hara dan air dengan cukup. Tanah regosol merupakan jenis tanah yang masih berkembang. Hasil penelitian dari Putinella (2011) pada tanah regosol di wilayah Rumah Tiga Ambon menunjukan bahwa tanah ini didominasi oleh fraksi pasir $(82,62 \%)$ diikuti oleh fraksi debu $(13,16 \%)$ dan fraksi liat $(4,22 \%)$ sehingga termasuk dalam kelas tekstur pasir berlempung. Selain sifat fisika, tanah regosol juga memiliki sifat kimia yang rendah. Hasil penelitian Sonbai (2013) pada tanah regosol menunjukan bahwa jenis tanah ini memiliki kadar C organik $(0,94 \%), \mathrm{N}$ tersedia $(70,95 \mathrm{ppm}), \mathrm{pH}$ $(6,24)$, KPK (6,04 me/100 g). Kondisi tanah regosol ini perlu dikelola guna meningkatkan produktivitasnya. Tanah regosol memiliki beberapa permasalahan seperti kemampuan menyerap dan menyimpan air yang sangat rendah serta peka terhadap pencucian unsur hara. Tingginya pencucian unsur hara pada regosol mengakibatkan pemupukan tidak efisien.

Bahan organik tersedia berkisar 3-5\% dalam tanah (Hardjowigeno, 2003). Penambahan kadar bahan organik dapat membantu mempertahankan dan memperbaiki kesuburan dan produktifitas tanah. Hasil penelitian Sonbai et al. (2013) menyatakan bahan organik pupuk kandang 10ton/ha mampu memberikan hasil tertinggi dalam peningkatan ketersediaan hara nitrogen, produktivitas tanaman serta distribusi pori lebih baik pada tanah regosol. Hal ini sejalan dengan penelitian Helmi (2010) yang menyatakan pemberian bahan organik menghasilkan perubahan beberapa sifat fisika tanah regosol (berat volume tanah, porositas total, indeks stabilitas agregat dan agregasi tanah) serta meningkatkan hasil kacang tanah dan produktivitasnya hingga $32,84 \%$.

Bahan organik sangat penting bagi sifat fisika tanah, diantaranya dalam pembentukan dan pemantapan agregat tanah, porositas tanah, kadar air, permeabilitas tanah, bobot volume, dan total ruang pori tanah, serta sifat fisika lainnya. Sebagai contoh, tanah dengan kandungan bahan organik yang tinggi lebih mantap agregatnya dibandingkan dengan kandungan bahan organik yang rendah. Selain itu, kandungan bahan organik yang cukup pada tanah akan menciptakan struktur tanah remah, menyeimbangkan pori makro dan mikro, sehingga ketersediaan air dan udara tanah bagi pertumbuhan tanaman akan meningkat. Guna menjawab permasalahan tanah regosol, penelitian ini membahas mengenai kombinasi pemberian bahan organik dan kebutuhan air untuk dimanfaatkan seoptimal mungkin demi memperoleh hasil semaksimal mungkin guna mencukupi kebutuhan hara NPK pada tanah regosol.

Penelitian ini bertujuan untuk membandingkan volume air yang diberikan dengan frekwensi 1, 2 atau 3 hari sekali untuk ketersediaan hara NPK pada tanah regosol, Mengetahui banyaknya unsur hara NPK yang tersedia setelah 30 hari inkubasi dengan pemberian dosis kompos yang berbeda, serta mengetahui interaksi antara air dan dekomposisi bahan organik dalam menyediakan hara NPK pada tanah regosol. Hipotesis: Penambahan bahan organik sebanyak $10 \%(300 \mathrm{~g} / 3 \mathrm{~kg}$ tanah) yang diberi air 3 hari sekali mampu memineralisasi hara NPK, secara optimum dan lebih 
mengikat air dibandingkan dosis $5 \%$ bahan organik pada tanah regosol.

\section{METODE PENELITIAN}

Penelitian ini dilaksanakan di Rumah Kaca Fakultas Pertanian Universitas Pattimura Ambon, yang berlangsung dari bulan September sampai dengan Oktober 2017. Analisis pupuk kompos dan tanah dilakukan di Laboratorium Balittan Bogor dan di Laboratorium Jurusan Tanah Univesitas Brawijaya. Metode yang digunakan dalam penelitian ini adalah Rancangan acak lengkap dengan perlakuan sebagai berikut: A : Waktu pemberian air (pemberian air 1 hari sekali), (pemberian air 2 hari sekali) dan (pemberian air 3 hari sekali), B : Pemberian bahan organik (kompos dosis 5\% (150 g/3 kg tanah)) (kompos dosis 10\% (300 $\mathrm{g} / 3 \mathrm{~kg}$ tanah)), dan Kontrol. Setiap perlakuan diulang 3 kali, sehingga didapat 27 satuan percobaan.

\section{Analisis Karakteristik Kimia Kompos dan Tanah Awal (Sebelum Perlakuan) di Laboratorium}

Analisis kimia kompos meliputi: unsur $\mathrm{N}$ total, $\mathrm{P}$ tersedia, $\mathrm{K}$ tersedia dan $\mathrm{pH}\left(\mathrm{H}_{2} \mathrm{O}\right)$. Analisis kimia lengkap tanah awal meliputi: $\mathrm{pH}\left(\mathrm{H}_{2} \mathrm{O}\right)$, C-organik (Walkey Black), N-total (Kjehldal), P-tersedia (Bray I), $\mathrm{K}$-dd $\left(\mathrm{NH}_{4} \mathrm{OAC} 1 \mathrm{~N}\right)$, KTK $\left(\mathrm{NH}_{4} \mathrm{OAC} 1 \mathrm{~N} \mathrm{pH} \mathrm{7,0),} \mathrm{dan}\right.$ tekstur 3 fraksi dengan metode pipet.

\section{Menghitung kebutuhan air dengan program Cropwat}

Untuk mengetahui volume air yang dibutuhkan oleh tanah dengan mengeksekusi program Cropwat version 8.0 menggunakan input data klimatologi (suhu, curah hujan, kecepatan angin, lama penyinaran matahari, kelembapan, evaporasi) sepuluh tahun terakhir pada Pulau Ambon yang diperoleh dari Badan Meteorologi dan Geofisika di Laha. Cropwat juga dapat digunakan untuk mengevaluasi praktek-praktek irigasi petani dan untuk menilai kinerja tanaman di bawah kedua kondisi tadah hujan dan irigasi. Data input yang dibutuhkan untuk penggunaan Cropwat adalah: 1) data metereologi berupa suhu udara maksimun dan minimun, kelembaban relatif, lama penyinaran, kecepatan angin, evapotranspirasi tanaman, data curah hujan harian (periode atau bulanan); 2) data tanaman berupa tanggal penanaman, fase pertumbuhan tanaman, kedalaman perakaran tanaman dan luas areal tanam $(0-100 \%$ dari luas total area); dan 3) data jenis tanah.

\section{Pelaksanaan Penelitian}

Secara astronomis lokasi pengambilan tanah Regosol terletak pada koordinat $03^{\circ} 39^{\prime} 01,16^{\prime \prime}$ LS dan $128^{\circ} 11^{\prime} 35,47^{\prime \prime}$ BT (4 m dpl). Secara Adminstratif pada lingkungan kampus Universitas Pattimura, Desa Poka,
Ambon. Tanah diambil pada kedalaman 0-20 $\mathrm{cm}$ dan dikering anginkan. dari kedalaman 0-20 cm dan dikering anginkan. Kemudian diayak menggunakan ayakan $2 \mathrm{~mm}$ dan ditimbang seberat $3 \mathrm{~kg}$, selanjutnya kompos diberikan sesuai dosis $(0 \mathrm{~g} /$ pot, $150 \mathrm{~g} /$ pot, 300 g/pot) dan diberi label sesuai perlakuan (sebanyak 27 pot). Setelah itu pot ditempatkan dalam rumah kaca dan kemudian diberi perlakuan air dengan menggunakan gelas ukur sesuai dosis air hasil perhitungan Cropwat.

Tanah ditimbang ulang untuk dicatat beratnya setelah ditambahkan pelakuan air. Hasil pengukuran berat tanah dan pot yang telah diberi perlakuan air kemudian dicatat dan dijadikan kontrol untuk perlakuan air selanjutnya. Setiap awal pemberian air, tanah dan pot selalu diukur beratnya dengan menggunakan timbangan analitik serta diukur suhu tanahnya menggunakan alat 4 in 1 Soil Survey Instrument.

\section{Pemberian Air}

Pemberian air untuk setiap unit percobaan pada tahap awal sesuai hasil perhitungan Cropwat version 8.0 untuk A1, A2 dan A3 sebanyak 1,113 mL/hari. Selanjutnya pemberian air dilakukan setiap sore untuk perlakuan A1, 2 hari sekali untuk A2 dan 3 hari sekali untuk A3. Setiap perlakuan air yang diberikan menyesuaikan dari hasil pengukuran berat tanah dan pot yang telah diberikan air pada tahap awal. Perlakuan air selalu diberikan tepat pukul 17.00 WIT.

\section{Pengambilan contoh tanah untuk analisis $\mathbf{N}$ total, $\mathbf{P}$ tersedia, K-dd, pH dan C-organik}

Sampel tanah yang sudah diinkubasi selama 1 bulan dikeluarkan dari dalam pot dan dikeringanginkan. Kemudian tanah dicampur merata agar homogen dimasukkan kedalam plastik sebanyak $200 \mathrm{~g}$ dan diberi label lalu di kirim ke Laboratorium Jurusan Tanah Universitas Brawijaya untuk dianalisis $\mathrm{pH}\left(\mathrm{H}_{2} \mathrm{O}\right)$, Corganik (Walkley Black), N-total (Kjehldal), P-tersedia (Bray I), dan $\mathrm{K}$-dd $\left(\mathrm{NH}_{4} \mathrm{OH} 1 \mathrm{~N}\right)$.

\section{HASIL DAN PEMBAHASAN}

\section{Analisis Tanah Awal}

Karakteristik tanah Regosol yang digunakan dalam penelitian sebelum diberi perlakuan disajikan pada Tabel 1. Hasil analisis tanah regosol di lokasi penelitian menunjukkan bahwa tanah regosol didominasi oleh fraksi pasir (74\%). Hal itu menyebabkan luas permukaannya kecil dan pori makro lebih banyak sehingga kemampuan tanah untuk mengikat air relatif rendah. Hasil analisis kimia tanah menunjukkan bahwa terdapat kendala kesuburan dimana $\mathrm{pH}$ tanah agak masam dan nilai KTK rendah. 
Tabel 1. Hasil analisis kimia dan fisik tanah regosol sebelum perlakuan

\begin{tabular}{ccc}
\hline Unsur & Nilai & Kriteria* \\
\hline Pasir $(\%)$ & 74 & \\
Liat $(\%)$ & 8 \\
Debu (\%) & 18 \\
C-Organik (\%) & 2,9 & Lempung berpasir \\
N-Total (\%) & 0,22 & Sedang \\
Rasio C/N & 13 & Sedang \\
Ptersedia (mg/kg) & 5,0 & Sedang \\
K-dd (me/100 g) & 0,15 & Rendah \\
pH $\left(\mathrm{H}_{2} \mathrm{O}\right)$ & 6,0 & Rendah \\
KTK cmol $/ \mathrm{kg}$ & 9,66 & Agak Masam \\
R & Rendah \\
\hline
\end{tabular}

Keterangan: ${ }^{*}$ Kriteria Balittan, Bogor (Hardjowigeno, 2007)

Tabel 2. Hasil analisis kimia kompos

\begin{tabular}{cccc}
\hline No & Sifat Kimia & & Nilai \\
\hline 1 & $\mathrm{pH}$ & 7,97 & \\
2 & $\mathrm{C}$ organik $(\%)$ & 13,32 & \\
3 & $\mathrm{~N}$ total $(\%)$ & 0,78 & \\
4 & $\mathrm{C} / \mathrm{N}$ & 14,3 & \\
5 & $\mathrm{P}_{2} \mathrm{O}_{5}$ total $(\%)$ & 0,18 & \\
6 & $\mathrm{~K}_{2} \mathrm{O}$ total $(\%)$ & 2,13 & \\
\hline
\end{tabular}

Sumber: Siregar dan Huliselan (2014)

Kapasitas tukar kation merupakan sifat kimia yang sangat erat hubungannya dengan kesuburan tanah. Tanah dengan kapasitas tukar kation tinggi mampu menjerap dan menyediakan unsur hara lebih baik daripada tanah dengan kapasitas tukar kation rendah.

Dari karakteristik tanah hasil analisis awal, menunjukkan bahwa regosol memiliki kesuburan tanah yang relatif rendah sehingga penambahan bahan organik pada tanah perlu dilakukan. Penambahan kadar bahan organik dapat membantu mempertahankan dan memperbaiki kesuburan dan produktifitas tanah. Hal ini sejalan dengan penelitian Helmi (2010) yang menyatakan pemberian bahan organik menghasilkan perubahan beberapa sifat fisika tanah regosol (berat volume tanah, porositas total, indeks stabilitas agregat dan agregasi tanah).

\section{Hasil Analisis Kompos}

Hasil analisis sifat kimia yang terkandung di dalam pupuk kompos dapat dilihat pada Tabel 2.

Hasil analisis kompos menghasilkan $\mathrm{N}$ total sebesar 0,78\% sesuai dengan standar SNI 19-7030-2004 yaitu $>0,40 \%$. Sebagian besar nitrogen dalam tanah didapatkan dalam bentuk organik. Kompos yang diperoleh sudah matang, hal ini ditandai dengan nilai $\mathrm{C} / \mathrm{N}$ yang rendah yaitu 14,3 dan sesuai dengan standar nilai SNI 19-7030-2004 yaitu 10-20.

Kadar $\mathrm{N}$ total memiliki kaitan dengan kadar $\mathrm{C}$ organik karena selama proses pengomposan mikroorganisme menggunakan $\mathrm{C}$ sebagai sumber energi untuk sintesis selnya melalui proses dekomposisi dan aktivitas respirasi menghasilkan $\mathrm{CO}_{2}$ yang kemudian menurunkan kadar $\mathrm{C}$ dan meningkatkan kadar $\mathrm{N}$ tanah.
Apabila nilai C/N kompos terlalu tinggi yaitu 50 menunjukkan bahwa bahan organik belum terdekomposisi sempurna sebaliknya nilai $\mathrm{C} / \mathrm{N}$ yang semakin rendah (17-25) menunjukkan bahwa bahan organik sudah terdekomposisi dengan baik. Pada nilai $\mathrm{C} / \mathrm{N}$ di antara 30-40 mikroba mendapatkan cukup C untuk energi dan $\mathrm{N}$ untuk sintesis protein. Apabila nilai $\mathrm{C} / \mathrm{N}$ terlalu tinggi, mikroba akan kekurangan $\mathrm{N}$ untuk sintesis protein sehingga dekomposisi berjalan lambat. Pada kompos dengan kandungan rasio $\mathrm{C} / \mathrm{N}$ rendah akan banyak mengandung amoniak $(\mathrm{NH})$ yang dihasilkan oleh bakteri amoniak. Senyawa ini dapat dioksidasi lebih lanjut menjadi nitrit dan nitrat yang mudah diserap oleh tanaman. Perbandingan $\mathrm{C} / \mathrm{N}$ terlalu rendah juga akan menyebabkan terbentuknya gas amoniak, sehingga nitrogen mudah hilang ke udara (Roidah, 2013).

Pada penelitian ini kompos yang digunakan termasuk kompos yang telah terdekomposisi dengan baik karena rasio $\mathrm{C} / \mathrm{N}$ rendah yaitu 14,3.

\section{Hasil Analisa Kimia Tanah}

Pengaruh frekuensi pemberian air dan bahan organik terhadap pH tanah

Tanah regosol memiliki $\mathrm{pH} \quad 6,0$, setelah diberikan perlakuan kompos dan air selama 1 bulan inkubasi terjadi penurunan nilai $\mathrm{pH}$ secara nyata, sedangkan interaksi kedua perlakuan tersebut tidak berpengaruh nyata.

Tabel 3 menunjukkan, perlakuan air terhadap penurunan nilai $\mathrm{pH}$ terendah yaitu 5,22 pada perlakuan pemberian air satu hari sekali (A1), kemudian $\mathrm{pH}$ menurun sampai mencapai $\mathrm{pH}$ terendah yaitu 5,07 pada perlakuan pemberian air 3 hari sekali (A3). 
Tabel 3. Pengaruh perlakuan air terhadap $\mathrm{pH}$ tanah

\begin{tabular}{cc}
\hline Penyiraman & Rataan \\
\hline Setiap hari & $5,22 \mathrm{a}$ \\
2 hari sekali & $5,10 \mathrm{~b}$ \\
3 hari sekali & $5,07 \mathrm{~b}$ \\
\hline
\end{tabular}

Keterangan: Angka-angka yang diikuti dengan huruf yang sama tidak berbeda nyata pada uji beda BNT 0,05 = 0,12

Dari hasil analisis, diperoleh $\mathrm{pH}$ tertinggi ialah 5,22 (A1), sudah termasuk kriteria masam pada perlakuan pemberian air satu hari sekali. Terlihat bahwa semakin sering pemberian air pada tanah maka cenderung semakin rendah nilai $\mathrm{pH}$ tanah. Keasaman tanah ditentukan oleh kadar atau kepekatan ion hidrogen di dalarn tanah tersebut. Bila kepekatan ion hidrogen di dalam tanah terlalu tinggi maka tanah akan bereaksi asam. Sebaliknya, bila kepekatan ion hidrogen terIalu rendah maka tanah akan bereaksi basa. Pada kondisi ini kadar kation $\mathrm{OH}^{-}$lebih tinggi dari ion $\mathrm{H}^{+}$.

Pada tanah masam lahan kering banyak ditemukan ion $\mathrm{Al}^{3+}$ yang bersifat masam karena dengan air ion tersebut dapat menghasilkan $\mathrm{H}^{+}$. Dalarn keadaan tertentu, yaitu apabila tercapai kejenuhan ion $\mathrm{Al}^{3+}$ tertentu, terdapat juga ion Al-hidroksida dengan cara sebagai berikut:

$$
\begin{gathered}
\mathrm{Al}^{3+}+3 \mathrm{H}_{2} \mathrm{O}-\mathrm{Al}(\mathrm{OH})^{2+}+\mathrm{H}^{+} \\
\mathrm{Al}^{3+}+\mathrm{OH}^{-}-\mathrm{Al}(\mathrm{OH})^{2+}
\end{gathered}
$$

Kebanyakan partikel lempung berinteraksi dengan ion $\mathrm{H}^{+}$. Lempung jenuh hidrogen mengalami dekomposisi spontan. Ion hidrogen menerobos lapisan oktahedral dan menggantikan atom Al. Aluminium yang dilepaskan kemudian dijerap oleh kompleks lempung dan suatu kompleks lempung-Al-H terbentuk dengan cepat ion. $\mathrm{Al}^{3+}$ dapat terhidrolisis dan menghasilkan ion $\mathrm{H}^{+}: \mathrm{H}$

$$
\text { lempung }-\mathrm{Al}^{3+}+3 \mathrm{H}_{2} \mathrm{O}-\underset{\mathrm{H}+\mathrm{H}}{-\mathrm{Al}}(\mathrm{OH}) 3+\mathrm{H}-\text { lempung }-=
$$

Reaksi tersebut menyumbang pada peningkatan konsentrasi ion $\mathrm{H}^{+}$dalam tanah. Air yang diberikan setiap hari sekali menyebabkan proses pelarutan asamasam menjadi lebih intensif. Makin tinggi kadar ion $\mathrm{H}^{+}$ di dalam tanah, maka semakin masam tanah tersebut.

Tabel 4. Pengaruh perlakuan bahan organik terhadap $\mathrm{pH}$ tanah

\begin{tabular}{cc}
\hline Bahan organik $(\mathrm{g} / \mathrm{pot})$ & Rataan \\
\hline 0 & $5,25 \mathrm{a}$ \\
150 & $5,13 \mathrm{~b}$ \\
300 & $5,01 \mathrm{c}$ \\
\hline
\end{tabular}

Keterangan: angka-angka yang diikuti dengan huruf yang sama tidak berbeda nyata pada uji beda BNT 0,05 = 0,12 .

Tabel 4 menunjukkan, perlakuan bahan organik terhadap penurunan nilai $\mathrm{pH}$ terendah yaitu 5,25 pada perlakuan tanpa bahan organik, kemudian $\mathrm{pH}$ menurun sampai mencapai $\mathrm{pH}$ terendah yaitu 5,01 pada perlakuan bahan organik $300 \mathrm{~g} /$ pot.

Dari hasil analisis, diperoleh $\mathrm{pH}$ terendah ialah 5,01 (B2), sudah termasuk kriteria masam pada perlakuan bahan organik $300 \mathrm{~g} /$ pot. Terlihat bahwa semakin tinggi taraf bahan organik dalam tanah cenderung semakin rendah nilai $\mathrm{pH}$ tanah. Hal ini disebabkan karena dekomposisi dari bahan organik banyak menghasilkan asam-asam organik sehingga $\mathrm{pH}$ menurun. Bahan organik yang telah terdekomposisi mempunyai gugus reaktif, seperti karboksil (-COOH) dan fenol $(\mathrm{OH})$ yang mendominasi kompleks pertukaran dan bertindak sebagai asam lemah sehingga dapat terdisosiasi dan menghasilkan ion $\mathrm{H}^{+}$, sehingga $\mathrm{pH}$ tanah menurun.

\section{Pengaruh frekuensi pemberian air dan bahan organik terhadap $\mathbf{C}$ organik tanah}

Tanah regosol mengandung 2,9\% C organik, setelah diberikan perlakuan kompos selama 1 bulan inkubasi terjadi peningkatan kadar $\mathrm{C}$ organik secara nyata, sedangkan perlakuan pemberian air dan interaksi tidak berpengaruh nyata.

Tabel 5. Pengaruh perlakuan bahan organik terhadap C organik

\begin{tabular}{cc}
\hline Perlakuan & Rataan $(\%)$ \\
\hline B0 & $3,42 \mathrm{c}$ \\
B1 & $4,13 \mathrm{~b}$ \\
B2 & $4,98 \mathrm{a}$ \\
\hline
\end{tabular}

Keterangan: Angka-angka yang diikuti dengan huruf yang sama tidak berbeda nyata pada uji beda BNT $0,05=$ 0,36

Tabel 5 menunjukkan, perlakuan tanpa bahan organik (B0) menunjukan kadar C organik yaitu 3,42\%, kemudian kadar $\mathrm{C}$ organik meningkat sejalan dengan peningkatan dosis bahan organik sampai mencapai kadar C organik tertinggi yaitu 4,98\% pada perlakuan bahan organik $300 \mathrm{~g} /$ pot (B2).

Adanya penambahan bahan organik berbanding lurus dengan peningkatan $\mathrm{C}$ organik tanah. Roidah (2013) menjelaskan bahwa dengan pemberian bahan organik dapat meningkatkan kandungan $\mathrm{C}$ organik tanah dan juga dengan peningkatan $\mathrm{C}$ organik tanah juga dapat mempengaruhi sifat tanah menjadi lebih baik secara fisik, kimia dan biologi. Karbon merupakan sumber makanan mikroorganisme tanah, sehingga keberadaan $\mathrm{C}$ organik dalam tanah akan memacu kegiatan mikroorganisme sehingga meningkatkan proses dekomposisi tanah dan juga reaksi-reaksi yang memerlukan bantuan mikroorganisme, misalnya pelarutan $\mathrm{P}$, dan fiksasi $\mathrm{N}$.

Hasil analisis, diperoleh $\mathrm{C}$ organik tertinggi ialah $4,98 \%$ (B2), sudah termasuk kriteria tinggi pada perlakuan bahan organik $300 \mathrm{~g} /$ pot. Terlihat bahwa semakin tinggi taraf bahan organik dalam tanah cenderung semakin tinggi $\mathrm{C}$ organik tanah. 


\section{Pengaruh frekuensi pemberian air dan bahan organik terhadap $\mathbf{N}$ total tanah}

Tanah regosol mengandung $0,22 \% \mathrm{~N}$, setelah diberikan perlakuan kompos selama 1 bulan inkubasi terjadi peningkatan $\mathrm{N}$ total secara nyata, sedangkan perlakuan pemberian air dan interaksi kedua perlakuan tersebut tidak berpengaruh nyata.

Tabel 6. Pengaruh perlakuan bahan organik terhadap N total

\begin{tabular}{cc}
\hline Perlakuan & Rataan $(\%)$ \\
\hline B0 & $0,40 \mathrm{~b}$ \\
B1 & $0,42 \mathrm{~b}$ \\
B2 & $0,53 \mathrm{a}$ \\
\hline
\end{tabular}

Keterangan: Angka-angka yang diikuti dengan huruf yang sama tidak berbeda nyata pada uji beda BNT $0,05=$ 0,02

Tabel 6 menunjukkan, perlakuan tanpa bahan organik (B0) menunjukan nilai $\mathrm{N}$ total terendah yaitu $0,40 \%$, kemudian nilai $\mathrm{N}$ total meningkat sejalan dengan peningkatan dosis bahan organik sampai mencapai $\mathrm{N}$ total tertinggi yaitu $0,53 \%$ pada perlakuan bahan organik $300 \mathrm{~g} /$ pot (B2). Kandungan N pada perlakuan B1 tidak berbeda nyata dengan B0.

Peningkatan nilai $\mathrm{N}$-total tanah ini berasal dari mineralisasi bahan organik yang diberikan. Nitrogen merupakan hara makro utama yang sangat penting untuk pertumbuhan tanaman. Nitrogen diserap oleh tanaman dalam bentuk ion $\mathrm{NO}_{3}{ }^{-}$atau $\mathrm{NH}_{4}{ }^{+}$dari tanah. Nitrogen anorganik digunakan oleh mikroorganisme untuk sintesis selnya yang disebut immobilisasi atau asimilasi N. Proses transformasi N organik menjadi ammonium oleh enzim nitrogenase yang dihasilkan oleh mikroorganisme tanah disebut amonifikasi. Enzim ekstraselluler yang dihasilkan mikroorganisme mendegradasi protein, aminopolisakarida (dinding sel mikroorganisme) dan asam nukleat (Handayanto dan Hairiah, 2007). Selanjutnya, $\mathrm{NH}_{4}{ }^{+}$ini dioksidasi oleh mikroorganisme nitrifikasi berubah menjadi $\mathrm{NO}_{3}{ }^{-}$.

Reaksi penguraian protein oleh mikroorganisme:

Protein + Enzim $\rightarrow$ Senyawa amino $+\mathrm{CO}_{2}+\mathrm{E}$

$$
\begin{gathered}
\mathrm{R}-\mathrm{NH}_{2}+\mathrm{H}_{2} \mathrm{O} \rightarrow \mathrm{R}-\mathrm{OH}+\mathrm{NH}_{3}+\mathrm{E} \\
\mathrm{NH}_{3}+\mathrm{HOH} \rightarrow \mathrm{NH}_{4} \mathrm{OH} \rightleftarrows \mathrm{NH}_{4}^{+}+\mathrm{OH}^{-} \\
2 \mathrm{NH}_{4}^{+}+3 \mathrm{O}_{2} \rightarrow 2 \mathrm{NO}_{2}^{-}+2 \mathrm{H}_{2} \mathrm{O}+4 \mathrm{H}^{+}+\mathrm{E} \\
2 \mathrm{NO}_{2}^{-}+\mathrm{O}_{2} \rightarrow 2 \mathrm{NO}_{3}^{-}+\mathrm{E}
\end{gathered}
$$

Ketersedian unsur $\mathrm{N}$ dalam tanah merupakan salah satu faktor penting untuk menunjang pertumbuhan dan perkembangan tanaman, namun ketersediaan unsur nitrogen dalam tanah sering sangat terbatas. Sumber nitrogen $(\mathrm{N})$ paling banyak terdapat di atmosfer, yaitu 78-80\%. Dalam bentuk $\mathrm{N}_{2}$, nitrogen tidak dapat langsung dimanfaatkan oleh tanaman sehingga perlu diubah terlebih dahulu menjadi nitrat atau ammonium agar dapat tersedia bagi tanaman.

Pendekatan untuk meningkatkan efisiensi penggunaan $\mathrm{N}$ yang tersedia dalam tanah adalah penggunaan bahan organik dan mikroorganisme. Bahan organik secara langsung merupakan sumber hara $\mathrm{N}$ dan secara tidak langsung bahan organik membantu menyediakan energi bagi bakteri penambat $\mathrm{N}_{2}$ melalui $\mathrm{C}$ organik yang digunakan sebagai sumber energi. Selain bahan organik, sebagian besar mikroorganisme tumbuh baik pada suhu $25-45^{\circ} \mathrm{C}$. Pada penelitian ini rata-rata suhu hasil pengukuran ialah $28-33^{\circ} \mathrm{C}$. Sehingga mikroorganisme bisa bekerja dengan maksimal.

Hasil analisis, diperoleh kandungan N-total tertinggi ialah $0,53 \%$ (B2), sudah termasuk kriteria tinggi pada perlakuan bahan organik $300 \mathrm{~g} /$ pot yang berarti tanah pada perlakuan tersebut termasuk tanah yang baik untuk bercocok tanam karena nitrogen berfungsi untuk merangsang pertumbuhan tanaman secara keseluruhan seperti batang, cabang dan daun.

\section{Pengaruh perlakuan pemberian air dengan bahan organik terhadap $\mathbf{P}$ tersedia tanah}

Tanah regosol mengandung $5 \mathrm{mg} / \mathrm{kg} \mathrm{P}$ tersedia, setelah diberikan perlakuan Kompos selama 1 bulan inkubasi terjadi peningkatan $\mathrm{P}$ tersedia secara nyata, sedangkan perlakuan pemberian air dan interaksi kedua perlakuan tersebut tidak berpengaruh nyata.

Tabel 7. Pengaruh perlakuan bahan organik terhadap $P$ tersedia

\begin{tabular}{cc}
\hline Perlakuan & Rataan $(\mathrm{mg} / \mathrm{kg})$ \\
\hline B0 & $1,42 \mathrm{c}$ \\
B1 & $4,99 \mathrm{~b}$ \\
B2 & $17,50 \mathrm{a}$ \\
\hline
\end{tabular}

Keterangan: Angka-angka yang diikuti dengan huruf yang sama tidak berbeda nyata pada uji beda BNT $0,05=$ 2,57

Tabel 7 menunjukkan, perlakuan tanpa bahan organik (B0) menunjukan nilai $\mathrm{P}$ tersedia terendah yaitu $1,42 \mathrm{mg} / \mathrm{kg}$, kemudian $\mathrm{P}$ tersedia meningkat sejalan dengan peningkatan dosis bahan organik sampai mencapai $\mathrm{P}$ tersedia tertinggi yaitu $17,50 \mathrm{mg} / \mathrm{kg}$ pada perlakuan bahan organik $300 \mathrm{~g} /$ pot (B2).

Fosfor merupakan unsur yang diperlukan dalam jumlah besar (hara makro). Jumlah fosfor dalam tanaman lebih kecil dibandingkan dengan nitrogen dan kalium. Tanaman menyerap fosfor dalam bentuk ion $\mathrm{H}_{2} \mathrm{PO}_{4}{ }^{-}$dan $\mathrm{HPO}_{4}{ }^{2-}$ (Rosmarkam dan Yuwono, 2002).

Dari hasil analisis, diperoleh kandungan $\mathrm{P}$ tersedia tertinggi ialah $17,50 \mathrm{mg} / \mathrm{kg}$ (B2), sudah termasuk kriteria tinggi pada perlakuan bahan organik $300 \mathrm{~g} /$ pot. Peningkatan P tersedia dalam tanah setelah inkubasi selama 1 bulan merupakan hasil dekomposisi dari bahan organik yang diaplikasikan yang mengandung $0,18 \% \quad \mathrm{P}_{2} \mathrm{O}_{5}$ total $(1800 \mathrm{mg} / \mathrm{kg})$. Proses dekomposisi dan mineralisasi yang terjadi pada $\mathrm{P}_{2} \mathrm{O}_{5}$ total menyebabkan ion fosfat lebih tinggi ketersediaannya di dalam tanah. 


\section{Pengaruh perlakuan pemberian air dengan bahan organik terhadap K-dd tanah}

Tanah regosol mengandung 0,15 me/100 g K-dd, setelah diberikan perlakuan pemberian air dan kompos selama 1 bulan inkubasi terjadi peningkatan K-dd secara nyata, sedangkan interaksi kedua perlakuan tersebut tidak berpengaruh nyata.

Tabel 8. Pengaruh perlakuan air terhadap K-dd tanah

\begin{tabular}{cc}
\hline Perlakuan & Rataan $(\mathrm{me} / 100 \mathrm{~g})$ \\
\hline $\mathrm{A} 1$ & $0,96 \mathrm{~b}$ \\
$\mathrm{~A} 2$ & $0,89 \mathrm{~b}$ \\
$\mathrm{~A} 3$ & $1,01 \mathrm{a}$ \\
\hline
\end{tabular}

Keterangan: Angka-angka yang diikuti dengan huruf yang sama tidak berbeda nyata pada uji beda BNT $0,05=$ 0,08

Tabel 8 menunjukkan, perlakuan air terhadap peningkatan nilai K-dd terendah yaitu $0,96 \mathrm{me} / 100 \mathrm{~g}$ pada perlakuan pemberian air sehari sekali, kemudian $\mathrm{K}$-dd meningkat sampai mencapai $\mathrm{K}$ tertinggi yaitu 1,01 me/100 g pada perlakuan pemberian air 3 hari sekali (A3).

Berdasarkan ketersediaannya, $\mathrm{K}$ di dalam tanah secara umum dikelompokkan menjadi tiga, yaitu $\mathrm{K}$ relatif tidak tersedia, $\mathrm{K}$ lambat tersedia, dan $\mathrm{K}$ tersedia. Kalium yang tersedia hanya meliputi $1-2 \%$ dari seluruh kalium yang terdapat pada tanah. Ia tersedia dalam tanah sebagai kalium dalam larutan tanah atau kalium yang dapat dipertukarkan dan di aborpsi oleh permukaan koloid tanah. Reaksi $\mathrm{K}$ di dalam tanah cukup rumit, karena berhubungan erat dengan reaksi pertukaran kation yang sangat bergantung pada tempat pertukaran (exchange site) dan keberadaan kation lain (Leiwakabessy et al., 2003).

Dari hasil analisis, diperoleh kandungan K-dd tertinggi ialah $1,01 \mathrm{me} / 100 \mathrm{~g}$ (B2), sudah termasuk kriteria tinggi pada perlakuan pemberian air 3 hari sekali. Hal ini terjadi karena air yang diserap oleh tanah pada pemberian 3 hari sekali (A3) lebih mampu diekstrak oleh mikroorganisme lebih baik dibandingkan dengan pemberian setiap hari (A1) dan 2 hari sekali (A2). Selain membantu dalam perombakan bahan organik oleh mikroorganisme, air juga berfungsi sebagai pelarut hara, air membantu proses pelarutan $\mathrm{K}$ dimana $\mathrm{K}$ dapat ditukar dilepaskan menjadi $\mathrm{K}$ larutan tanah sehingga lebih mudah diserap oleh tanaman. Besar kecilnya kandungan $\mathrm{K}$ di dalam tanah dikarenakan $\mathrm{K}$ di tanah terbentuk lebih stabil dari N, dan lebih cepat larut dibandingkan $\mathrm{P}$.

Tabel 9 menunjukkan, perlakuan tanpa bahan organik $0 \mathrm{~g} /$ pot (B0) menunjukan nilai $\mathrm{K}$-dd terendah yaitu $0,18 \mathrm{me} / 100 \mathrm{~g}$, kemudian $\mathrm{K}$-dd meningkat sejalan dengan peningkatan dosis bahan organik sampai mencapai K-dd tertinggi yaitu 2,03 me/100 g pada perlakuan bahan organik $300 \mathrm{~g} /$ pot (B2).
Tabel 9. Pengaruh perlakuan bahan organik terhadap K-dd

\begin{tabular}{cc}
\hline Perlakuan & Rataan $(\mathrm{me} / 100 \mathrm{~g})$ \\
\hline B0 & $0,18 \mathrm{c}$ \\
B1 & $0,66 \mathrm{~b}$ \\
B2 & $2,03 \mathrm{a}$ \\
\hline
\end{tabular}

Keterangan: Angka-angka yang diikuti dengan huruf yang sama tidak berbeda nyata pada uji beda BNT $0,05=$ 0,08

Pada umumnya kandungan bahan organik tanah regosol rendah, sehingga peningkatan kandungan bahan organik tanah akan membantu meningkatkan: a) KTK tanah sehingga $\mathrm{K}$ tidak mudah tercuci; dan $\mathrm{b}$ ) kemampuan tanah untuk menyimpan lengas tanah, sehingga memperlancar gerakan hara kalium.

Saat bahan organik pupuk kompos ditambahkan kedalam tanah, maka sebagian dari kalium akan terfiksasi sehingga menjadi bentuk yang tidak dapat dipertukarkan. Reaksi keseimbangan ini secara terus menerus akan menyebabkan sebagian dari kalium yang terikat akan dibebaskan menjadi bentuk dapat dipertukarkan dan selanjutnya kebentuk dalam larutan tanah. Selain itu, dengan penambahan bahan organik ke dalam tanah, bukan hanya sejumlah mikroorganisme yang bertambah di tanah tetapi mikroorganisme yang berada dalam tanah juga dipacu untuk berkembang (Roidah, 2013)

Dari hasil analisis, diperoleh kandungan K-dd tertinggi ialah 2,03 me/100 g sudah termasuk kriteria sangat tinggi pada perlakuan bahan organik $300 \mathrm{~g} /$ pot. Terlihat bahwa semakin tinggi taraf bahan organik dalam tanah cenderung semakin tinggi K-dd.

\section{KESIMPULAN}

1. Hasil penelitian menunjukkan bahwa pemberian air dan bahan organik secara mandiri memberikan pengaruh nyata terhadap kadar $\mathrm{N}, \mathrm{P}$, dan $\mathrm{K}$ dalam tanah. Sedangkan, interaksi antara kedua perlakuan air dan bahan organik tidak berpengaruh nyata terhadap kadar N, P, dan K dalam tanah.

2. Perlakuan pemberian air 3 hari sekali dan perlakuan bahan organik $300 \mathrm{~g} /$ pot (B2) adalah dosis yang lebih baik untuk peningkatan nilai $\mathrm{N}, \mathrm{P}$, dan $\mathrm{K}$ tertinggi yaitu $\mathrm{N}$ total $(0,53 \%), \mathrm{P}$ tersedia $(17,50$ $\mathrm{mg} / \mathrm{kg})$, dan K-dd (2,03 me/100 g).

\section{DAFTAR PUSTAKA}

Hardjowigeno, S. 2003. Klasifikasi Tanah dan Pedogenesis. Jakarta: CV. Akademika Pressindo.

Handayanto, E. dan K. Hairiyah. 2007. Biologi Tanah. Yogyakarta: Pustaka Adipura.

Helmi. 2010. Perubahan Beberapa Sifat Fisika Regosol dan Hasil Kacang Tanah Akibat Pemberian Bahan Organik dan Pupuk Fosfat. STIK. Banda Aceh. 
Leiwakabessy, F.M. dan A. Sutandi. 2003. Pupuk dan pemupukan. Jurusan Tanah, Fakultas Pertanian, Institut Pertanian Bogor. Bogor. 208 hal.

Nugraha, Y.S. 2013. Pengaruh Interval Waktu dan Tingkat Pemberian Air terhadap Pertumbuhan dan Hasil Tanaman Kedelai (Glycine max L. Merril.). Skripsi. Jurusan Budidaya Pertanian, Fakultas Pertanian, Universitas Pattimura Ambon.

Marsha, N.D. 2014. Studi Potensi Crotalaria mucronata Desv. Sebagai Pupuk Hijau. Skripsi. Universitas Brawijaya, Malang.

Pristianto, H. dan Mulyadi, M. 2015. Aplikasi Cropwat 8.0 Sebagai Upaya Menganalisa Kebutuhan Air Irigasi dan Hasil Produksi Tanamana Jagung Di Kelurahan Matalamagi Kota Sorong. Kondisi Daerah Irigasi di Wilayah Sorong.

Putinella, A. 2011. Perbaikan sifat fisik tanah regosol dan pertumbuhan tanaman sawi (Brassica juncea
L.) akibat pemberian bokashi ela sagu dan pupuk urea. Jurnal Budidaya Pertanian 7: 35-40.

Roidah, I.S. 2013. Manfaat Penggunaan Pupuk Organik Untuk Kesuburan Tanah. Jurnal Universitas Tulungagung Bonorowo 1: 30-42.

Rosmarkam, A. dan N.W. Yuwono. 2002. Ilmu Kesuburan Tanah. Yogyakarta: Kanisius.

Siregar, A. dan R. Huliselan. 2015. Percepatan Proses Pengomposan dengan Bioaktivator dari Limbah Pertanian dan Peluang Pemanfaatannya untuk Lahan Dusun. Pengelolaan Lanskap Agroforestri Wilayah Kepulauan Menghadapi Efek Perubahan Iklim. Ambon

Sonbai, J.H.H., D. Prajitno, dan A. Syukur. 2013. Pertumbuhan dan hasil jagung pada berbagai pemberian pupuk nitrogen di lahan kering regosol. Ilmu Pertanian 16: 77-89. DOI: https://doi.org/10.22146/ipas.2527 